\title{
Al-Muallaqat and their Emotive Meanings
}

\author{
Eyhab Abdulrazak Bader Eddin \\ English Department, Faculty of Languages and Translation \\ King Khalid University, Abha, Kingdom of Saudi Arabia \\ Said M. Shiyab \\ Director of Graduate Studies \\ Modern and Classical Language Studies \\ Kent State University, USA
}

\begin{abstract}
The objective behind this paper is to examine the concept of 'emotiveness in Arberry's translation of Al-Muallaqat, be it at the phonological, morphological, lexical and sematic levels. To achieve this end, an in-depth analysis of phrases and sentences will be carried out to see whetherArberry has succeeded in rendering all kinds of emotive meanings expressed in the AlMuallaqat. Samples subjected to the analysis will be taken from the Odes of five bards, namely: Imru' al-Qais, Tarafa, Zuhair, Antara, and Labid. The reason behind focusing on these odes is that they have cultural overtones that are difficult to capture in translation. These sentences and phrases will be discussed and analyzed in details, and their emotive meanings at all levels will be compared to those in the ST. After the analysis is conducted, conclusions will be drawn as to why Arberry has not accounted for the loss of emotive meaning that has led to the distortion of the source text (ST). This paper concludes with useful tips to overcome the mismatch inherent in emotive meaning-related problems.
\end{abstract}

Keywords :Arberry'stranslation, emotive meaning, expressive function, Al-Muallaqat Cite as: Shiyab, M. S. Bader Eddin, E.A. (2017). Al-Muallaqat and their Emotive Meanings. Arab World English Journal for Translation \& Literary

Studies, 1(1). DOI:http://dx.doi.org/10.24093/awejtls/vol1no1.1 